\title{
Increased Serum Immunoreactive Insulin in Rabbits Fed a Protein- and Mineral-Rich Diet.
}

\author{
L. G. Heding and H. Andersen \\ Novo Research Institute, Novo Allé, DK-2880 Bagsværd, Denmark \\ Received: October 18, 1972, and in revised form: April 13, 1973, accepted April 13, 1973
}

\begin{abstract}
Summary. In rabbits fed a diet of pellets containing approximately $12 \%$ protein, $4 \%$ fat, $44 \%$ nitrogen-free extracts and $1 \%$ calcium carbonate, serum immunoreactive insulin (IRI) was found to increase to values as high as $1134 \mu \mathrm{U} / \mathrm{ml}$ three hours after the intake of food. After oral glucose $(1.75 \mathrm{~g} / \mathrm{kg})$, glucose increased by an average of $105 \mathrm{mg} \%$ and IRI by $57 \mu \mathrm{U} / \mathrm{ml}$, whereas after $100 \mathrm{~g}$ of pellets these levels increased on the average by $45 \mathrm{mg} \%$ and $210 \mu \mathrm{U} / \mathrm{ml}$, respectively. There was a significant correlation between the IRI levels and the amount of food consumed, and a significant correlation $(P<0.001)$
\end{abstract}

between the glucose and IRI levels after intake of food. In rabbits that were fed natural diet such as sugar beet and oats, the increases in glucose and IRI were small. Addition of meat and bone meal as well as the mineralvitamin supplement containing up to $2 \mathrm{~g}$ calcium carbonate caused a considerable increase in glucose and IRI. It is suggested that the high amount of calcium in the feed stimulated the glucose-induced insulin release.

Key-words: Insulin release, protein, glucose, minerals, $\mathrm{CaCO}_{3}$, rabbits.

\section{Introduction}

During routine control of blood sugar and serum insulin in a large number of normal rabbits fed on a laboratory pellet diet, very high immunoreactive insulin (IRI) levels were observed in the fed animals. Therefore, a systematic investigation was undertaken of the effect of handling and composition of the diet on the serum glucose and insulin in normal rabbits. The IRI and glucose responses to oral glucose, to natural feed and to a synthetic diet (consisting of a mixture of protein, fat, carbohydrate, minerals and vitamins) are reported. The IRI values after increased food intake and the correlation between serum IRI and glucose are presented.

\section{Materials and Methods}

Normal, untreated albino rabbits (Rex) were used throughout the study, they were kept in cages $41 \mathrm{~cm}$ high, $62 \mathrm{~cm}$ long and $44 \mathrm{~cm}$ wide. Blood was obtained from a puncture of the marginal ear vein and allowed to clot for an hour at $0^{\circ}$ before centrifugation. Serum was stored. frozen at $-18^{\circ}$ until used. Oral glucose tolerance tests (OGTT) were performed after a $16 \mathrm{~h}$ fast by administration of $1.75 \mathrm{~g}$ of glucose $/ \mathrm{kg}$ as a $35 \%$ solution, by stomach tube. Serum glucose was determined by the glucose oxidase method after an uranyl acetate precipitation of the serum proteins (the Boehringer, Mannheim method). Serum insulin was determined according to Heding (1972) using anti-pork insulin guinea-pig serum (M 10), human insulin, lot MC 12569 with a biological activity of 25.7 i. U/mg (NOVO Insulin Laboratory) as the standard, and ${ }^{125}$ I-labeled pork insulin as the tracer. It was shown that human and rabbit insulins, whose amino acid compositions differ only in regard to one amino acid, gave identical standard curves in the immunoassay system used. The rabbits were routinely fed at 7 a.m. every day and had. water ad libitum. The composition of the pellets is shown in Table 1. The natural food consisted of sugar beet, hay, oats and lettuce. The vitamin-mineral mix (for composi- tion see Table 1) was used as additive together with $\mathrm{CaCO}_{3}$.

Table 1. Composition of pellets for rabbits (Boserup OH feed)

\begin{tabular}{lc} 
Meat-and-bone meal & $1.0 \%$ \\
Fish meal & $1.0 \%$ \\
Sunflower seed, peeled & $6.0 \%$ \\
Soybean oil cake & $1.5 \%$ \\
Lucerne green meal & $40.0 \%$ \\
Maize & $10.0 \%$ \\
Barley & $20.5 \%$ \\
Wheat bran & $18.25 \%$ \\
Calcium carbonate & $1.0 \%$ \\
Vitamin/mineral mix $306^{\mathrm{a}}$ & $0.75 \%$ \\
\hline
\end{tabular}

a Vitamin/mineral mix 306 contains $A, D_{3^{-}}, B_{1^{-}}, B_{12^{-}}$ and E-vitamins as well as niacinamide, D-pantothenic acid and choline chloride, mixed in: $76.25 \%$ wheat flour, $3.8 \%$ mangan oxide, $4.8 \%$ ferr. sulphate monohydrate, $0.36 \%$ copper sulphate, $0.072 \%$ cobolt sulphate, $1.65 \%$ zinc sulphate monohydrate, $0.05 \%$ potassium iodide, $9.268 \%$ calcium carbonate, $3.75 \%$ ethoxyquin (Santoquin).

Each gram of this mix contains: 18 int. units of $A$. vitamin, 6 int. units of $\mathrm{D}_{3}$-vitamin, $5 \mu \mathrm{g}$ of $\mathrm{B}_{1}$-vitamin, $12 \mu \mathrm{g}$ of $\mathrm{B}_{2}$-vitamin, $68 \mu \mathrm{g}$ og niacinamide, $30 \mu \mathrm{g}$ of D-pantothenic acid, $650 \mu \mathrm{g}$ of choline chloride, $25 \mu \mathrm{g}$ of $\mathrm{E}$-vitamin, $15 \mathrm{mg}$ of $\mathrm{B}_{12}$-vitamin.

\section{Results}

\section{Fasting Glucose and IRI Values in Normal Rabbits, Effect of Repeated Blood Sampling}

Table 2 shows glucose and IRI values in 6 normal fasting rabbits under the stress of 3 venous punctures performed by an experienced technician. It appears that glucose increases significantly whereas IRI tends to decrease. 
Glucose and IRI after OGTT

Table 3 shows the results of OGTT in 6 normal rabbits. The mean glucose increase observed during a period of from 0 to $30 \mathrm{~min}$ was $105 \mathrm{mg} \%$, and the increase in IRI averaged $57 \mu \mathrm{U} / \mathrm{ml}$.

Table 2. Effect of repeated punctures of the ear vein on serum glucose and IRI in 6 normal, untreated, fasting rabbits

\begin{tabular}{lcc}
\hline $\begin{array}{l}\text { Blood sampling } \\
\text { at }\end{array}$ & $\begin{array}{l}\text { Serum glucose, } \\
\text { mg\% } \%\end{array}$ & IRI, $\mu \mathrm{U} / \mathrm{ml}$ \\
& mean S.E.M. & mean \pm S.E.M. \\
\hline 0 & $98 \pm 4.0$ & $13.6 \pm 3.7$ \\
$30 \mathrm{~min}$ & $110 \pm 2.3$ & $10.3 \pm 1.0$ \\
$60 \mathrm{~min}$ & $122 \pm 5.4$ & $9.0 \pm 1.2$ \\
\hline
\end{tabular}

of the pellets see Table 1) is shown in Table 3 . Ingestion of pellets (between 50 and $100 \mathrm{~g}$ within the first $3 \mathrm{~h}$ ) induced significant rises both in serum glucose and IRI averaging $30 \mathrm{mg} \%$ and $148 \mu \mathrm{U} / \mathrm{ml}$, respectively. The variation in IRI was substantial even between animals that had consumed the same amount of feed.

Table 5 shows how the amounts of pellets consumed influenced the glucose and IRI levels. 94 rabbits were given $100 \mathrm{~g}$ of pellets ad libitum. Their food intake was measured $3 \mathrm{~h}$ later, and blood samples were drawn for IRI and glucose determinations. Three rabbits had consumed approximately $25 \mathrm{~g}, 19$ rabbits approximately $50 \mathrm{~g}, 55$ rabbits approximately $75 \mathrm{~g}$ and 17 rabbits had eaten $100 \mathrm{~g}$, corresponding to a protein

Table 3. Tariation in serum glucose and IRI in normal rabbits after intake of pellets and oral glucose (1.75 g/kg) as a function of time

\begin{tabular}{|c|c|c|c|c|c|c|c|c|c|}
\hline & & & fasting & $1 / 2 \mathrm{~h}$ & $1 \mathrm{~h}$ & $2 \mathrm{~h}$ & $3 \mathrm{~h}$ & $4 \mathrm{~h}$ & $5 \mathrm{~h}$ \\
\hline $\begin{array}{l}\text { Glucose } \\
\mathrm{mg} \%\end{array}$ & mean \pm S.E.M. & $\begin{array}{l}\text { pellets } \\
\text { (12 rabbits) }\end{array}$ & $131 \pm 2$ & - & $142 \pm 5$ & $159 \pm 9$ & $158 \pm 6$ & $161 \pm 7$ & $156 \pm 6$ \\
\hline $\begin{array}{l}\mathrm{IRI} \\
\mu \mathrm{U} / \mathrm{ml}\end{array}$ & mean \pm S.E.M. & & $8 \pm 2$ & - & $137 \pm 25$ & $134 \pm 28$ & $143 \pm 24$ & $151 \pm 58$ & $99 \pm 29$ \\
\hline $\begin{array}{l}\text { Glucose } \\
\mathrm{mg} \%\end{array}$ & mean \pm S.E.M. & $\begin{array}{l}\text { glucose } \\
\text { (6 rabbits) }\end{array}$ & $120 \pm 2$ & $225 \pm 7$ & $216 \pm 9$ & $147 \pm 12$ & - & $145 \pm 3$ & \\
\hline $\begin{array}{l}\mathrm{IRI} \\
\mu \mathrm{U} / \mathrm{ml}\end{array}$ & mean \pm S.E.M. & & $9 \pm 2$ & $66 \pm 10$ & $68 \pm 19$ & $13 \pm 4$ & - & $6 \pm 2$ & \\
\hline
\end{tabular}

Table 4. Effect of oats + sugar beet + hay feed $(50 \mathrm{~g}+250 \mathrm{~g}+\tilde{0} 0 \mathrm{~g})$ on serum glucose and IRI in 12 normal rabbits

\begin{tabular}{|c|c|c|c|c|c|c|c|c|}
\hline \multirow[b]{2}{*}{$\begin{array}{l}\text { No. of Weeks } \\
\text { since start of } \\
\text { oats + beet + hay } \\
\text { feed }\end{array}$} & \multicolumn{4}{|c|}{ Prior to feeding } & \multicolumn{4}{|c|}{$3 \mathrm{~h}$ after feeding } \\
\hline & $\begin{array}{l}\text { Serum } \\
\text { glucose } \\
\text { mean } 1 \\
\text { S.E.M. }\end{array}$ & $\begin{array}{l}\mathrm{mg} \% \\
\text { (range) }\end{array}$ & $\begin{array}{l}\text { TRI, } \\
\text { mean } \pm \\
\text { S.E.M. }\end{array}$ & $\begin{array}{l}\mathrm{uU} / \mathrm{ml} \\
\text { (range) }\end{array}$ & $\begin{array}{l}\text { Serum } \\
\text { glucose, } \\
\text { mean } \pm \\
\text { S.E.M. }\end{array}$ & $\begin{array}{l}\mathrm{mg} \% \\
\text { (range) }\end{array}$ & $\begin{array}{l}\text { IRI, } \\
\text { mean } \neq \\
\text { S.E.M. }\end{array}$ & $\begin{array}{l}\text { u/mal } \\
\text { (range) }\end{array}$ \\
\hline $\begin{array}{l}1 \text { week } \\
2 \text { weeks } \\
3 \text { weeks }\end{array}$ & $\begin{array}{l}122 \pm 4.5 \\
120 \pm 3.9 \\
115 \pm 4.5\end{array}$ & $\begin{array}{r}(100-165) \\
(109-157) \\
(98-158)\end{array}$ & $\begin{array}{l}15 \pm 2.2 \\
18 \pm 2.2 \\
12 \pm 1.8\end{array}$ & 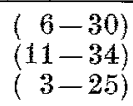 & $\begin{array}{l}125 \pm 5.2 \\
121 \pm 1.9 \\
132 \pm 4.9\end{array}$ & $\begin{array}{l}(106-173) \\
(107-134) \\
(111-161)\end{array}$ & $\begin{array}{l}29.7 \pm 6.4 \\
37.6 \pm 6.8 \\
52^{\mathrm{a}} \pm 2.6\end{array}$ & 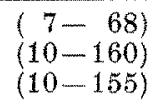 \\
\hline
\end{tabular}

a change from prior-to-feed level significant, $p<0.01$ (paired t-test).

\section{Glucose and IRI after Natural Food}

Rabbits fed beet and lettuce ad libitum showed no increase in glucose and IRI two hours after they started eating. When rabbits were fed oats, sugar beet and hay $(50 \mathrm{~g}+250 \mathrm{~g}+50 \mathrm{~g})$, variations were recorded in glucose and IRI as shown in Table 4. The glucose increase after intake of food was small and insignificant. A significant increase in IRI was recorded only on one out of three occasions, after 3 weeks of feeding oats and beet. During the $3 \mathrm{~h}$, the rabbits had eaten between one-quarter and one-half of the feed.

\section{Glucose and IRI after Pellets}

The variation in glucose and IRI as a function of time after intake of $100 \mathrm{~g}$ of pellets (for composition intake of $3-12 \mathrm{~g}$. All the animals showed an increase in glucose and all except one showed an increase in IRI. It appears from Table 5 that IRI levels rise significantly with increasing food intake. The correlation between interdependent glucose and IRI concentrations in serum $3 \mathrm{~h}$ after the intake of food was determined in 140 cases (none was left out) and the correlation coefficient found to be 0.59 , which is highly significant $(P<0.001)$.

\section{IRI Increase after Single Pellet Constituents}

Some of the components of pellets (bone meal and vitamin-mineral mix $+\mathrm{CaCO}_{3}$ ) were added to the sugarbeet-and-oats feed in order to see if it was possible to reproduce the increase in the IRI release. The 
powdered components were placed on top of the oats, but they dropped to the bottom of the feeding trough to a greater or lesser degree in the course of feeding so that the intake of components was not reproducible, for which reason these experiments were discontinued. Nevertheless, it could be concluded (Table 6) that there was a considerable and significant rise in the IRI levels in rabbits that had access to bone meal and vitamin + mineral mix containing $\mathrm{CaCO}_{3}$. A few efforts were made to force the components on the rabbits either in form of a slurry or capsulated, but the animals refused to eat. Gastric tube feeding was also tried but this involved increases in blood glucose due to insertion of the tube, and this method was abandoned. estimates. Finally, $1640 \mu \mathrm{U}$ of extracted IRI was electrophoresed in polyacrylamide gel at $\mathrm{pH}$ 8.7. After electrophoresis, the $6 \mathrm{~cm}$ long gel was cut into 32 pieces and each piece eluted with the immunoassay buffer and assayed for IRI. Only one peak of IRI was found, which contained $1540 \mu \mathrm{U}$ of IRI at the site of insulin. However, the position of rabbit proinsulin is not known in this electrophoresis system.

\section{Discussion}

It is well known that many ingredients of food other than carbohydrates induce the release of insulin.

Table 5. Variation in serum glucose and IRI as a function of the amount of pellets eaten three hours after food intake

\begin{tabular}{|c|c|c|c|c|c|c|}
\hline & & \multicolumn{5}{|c|}{$\begin{array}{l}\text { amount of pellets eaten in } \mathrm{g} \\
\text { (number of rabbits) }\end{array}$} \\
\hline & & $\begin{array}{c}0 \\
(94)\end{array}$ & $\begin{array}{l}25 \\
(3)\end{array}$ & $\begin{array}{l}50 \\
(19)\end{array}$ & $\begin{array}{l}75 \\
(55)\end{array}$ & $\begin{array}{l}100 \\
(17)\end{array}$ \\
\hline $\begin{array}{l}\text { Glucose } \\
\mathrm{mg} \%\end{array}$ & $\begin{array}{l}\text { mean } \frac{1}{ \pm} \text { S.E.M. } \\
\text { (range) }\end{array}$ & $\begin{array}{l}117 \pm 1 \\
(94=139)\end{array}$ & $\begin{array}{c}141 \pm \begin{array}{c}9 \\
(132-158)\end{array}\end{array}$ & $\begin{array}{c}136 \pm \begin{array}{c}3 \\
(117-158)\end{array}\end{array}$ & 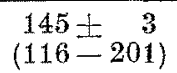 & 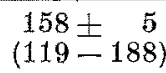 \\
\hline $\begin{array}{l}\operatorname{IRI} \\
\mu \mathrm{U} / \mathrm{ml}\end{array}$ & $\underset{\text { (range) }}{\operatorname{mean}} \pm$ S.E.M. & $\begin{array}{c}6 \pm 1 \\
(0-30)\end{array}$ & $\begin{array}{c}21 \pm 7 \\
(10=34)\end{array}$ & $\begin{array}{c}48 \pm 12 \\
(14-246)\end{array}$ & $\begin{array}{r}128 \pm 18 \\
(4-636)\end{array}$ & $\begin{array}{l}216 \pm 66 \\
(44-498)\end{array}$ \\
\hline
\end{tabular}

Table 6. Increase in IRI 90 min after intake of bone meal or vitamin + mineral + $\mathrm{CaCO}_{3}$ mix as a supplement to sugar beet and oats diet

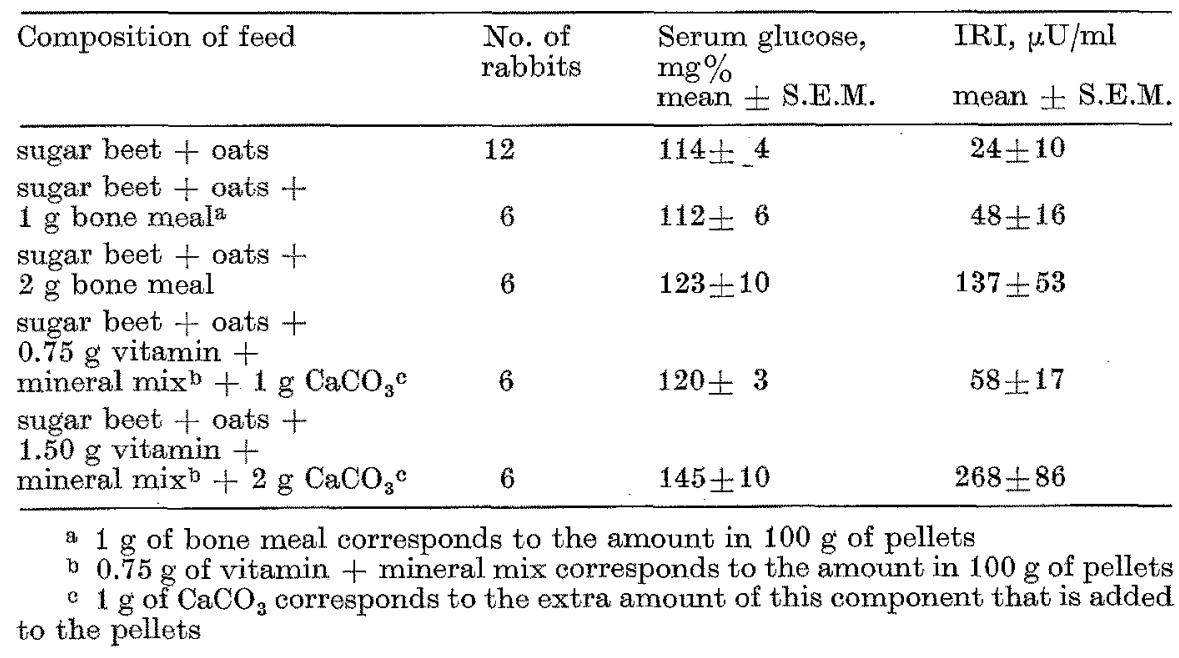

Characterization of IRI in Rabbit Serum after Pellets

The very high IRI values (up to $1134 \mu \mathrm{U} / \mathrm{ml}$; this value was measured in a series of rabbits not shown in this paper) measured in the rabbits $3 \mathrm{~h}$ after intake of food were checked in order to ensure that the immunoreactivity really was due to insulin. Serial dilutions and recovery experiments yielded the expected values. Acid ethanol extraction (Heding 1972), which separates insulin from the bulk of serum proteins including proteolytic enzymes, gave IRI values in the extracts that were not significantly different from the direct
Certain amino acids as well as proteins induce a release of insulin in normal persons. Knopf et al. (1966), Floyd et al. (1966a) and Fajans et al. (1972) showed that the infusion of $30 \mathrm{~g}$ of arginine, lysine or leucine in normal subjects increased the (basal) IRI levels from about $10 \mu \mathrm{U} / \mathrm{ml}$ to approximately 80,60 and $30 \mu \mathrm{U} / \mathrm{ml}$, respectively, whereas valine and phenyl-alanine caused only small increases and histidine and methionine no increase at all. Floyd et al. (1966 b) reported an increase of $10-40 \mu \mathrm{U} / \mathrm{ml}$ in the IRI level after a 500 -g-protein meal consisting of either liver or ground beef. Similar 
findings were reported by Sukkar et al. (1967) and Copinschi et al. (1967). Rabinowitz et al. (1966) compared the IRI release after oral glucose, beef and glucose plus beef in normal human subjects and found a substantially augmented rise in plasma insulin after glucose plus beef (max. serum IRI approx. $150 \mu \mathrm{U} / \mathrm{mI}$ ) as compared to glucose alone $(70 \mu \mathrm{U} / \mathrm{ml})$ and beef alone $(30 \mu \mathrm{U} / \mathrm{ml})$. Chick and Like (1971) fed various diets to mice with hereditary diabetes and found that a synthetic diet consisting of a combination of carbohydrates, proteins and fat gave the highest serum IRI levels. The exact composition of this diet and the IRI values in normal mice were not reported.

Although it has been recognized that many food ingredients induce the release of IRI, glucose is still considered to be the most important stimulant of insulin release.

A non-sedated rabbit will respond to stress such as a venous puncture with a quick rise in blood glucose. This response is especially pronounced in inexperienced laboratory animals. We have observed an increase of about $50 \mathrm{mg} \%$ glucose within a minute during a painful venous puncture. Table 2 shows that venous puncture performed by an experienced technician causes an increase in blood glucose of about $10 \mathrm{mg} \%$ $30 \mathrm{~min}$ after sampling. Thus, increases in glucose between two blood samplings should be evaluated taking this point into consideration.

Following an oral glucose load (6 rabbits), the serum glucose increased by approximately $105 \mathrm{mg} \%$ while the insulin increased by approximately $45 \mu \mathrm{U} /$ $\mathrm{ml}$. After $100 \mathrm{~g}$ of pellets (19 rabbits), the average increases in glucose and IRI were $45 \mathrm{mg} \%$ and $210 \mu \mathrm{V}$. There was a significant correlation $(P \ll 0.001)$ between the IRI level and the glucose concentration after pellets. Since IRI secretion is stimulated by oral protein intake (Floyd et al. (1966), Rabinowitz et al. (1966)), it is probable that the $12 \%$ protein content of the pellets enhances the insulin release. It is possible that the pellets increased the level of glucagon, which has been shown to rise after protein in humans (Unger (1972)). However, Unger did not find any significant increase in glucose and reported only a small increase in IRI.

The protein content of the pellets cannot be solely responsible for the IRI-increases, since an insulin increase was observed after oats + sugar beet + vitamins and minerals (including $\mathrm{CaCO}_{3}$ ). In the animals fed only oats and sugar beet, the changes in glucose and IRI were minor, whereas the vitamin + mineral + $\mathrm{CaCO}_{3}$ supplement resulted in a rise in glucose and an enormous IRI release. The same was observed, though to a lesser degree, after a bone-meal supplement, which is rich in minerals (e.g. calcium) and protein. Although it was difficult to quantitate the amount of bone meal or vitamin and mineral mix (including $\mathrm{CaCO}_{3}$ ) eaten by the rabbits, there is no doubt that these additions caused the IRI increases. Malaisse et al. (1970), Malaisse \& Malaisse (1971) and Malaisse (1972) have shown that enhanced insulin secretion from isolated rat islets was associated with an increased calcium uptake by the islets. The in vitro rate of insulin secretion increased as a linear function of calcium uptake, and Malaisse et al. (1970) put forward the hypothesis that $\mathrm{Ca}^{++}$influx in the $\beta$-cell might trigger off the release of insulin. Recently, Böttger et al. (1972) have shown that an intraduodenal load of calcium chloride $(4.5 \mathrm{mmol} / \mathrm{kg} \mathrm{dog}$ ) caused a rise in gut GLI, whereas no changes were observed in IRI and glucose. The mineral-vitamin mix administered to the rabbits contained $10-20 \mathrm{mmol} \mathrm{CaCO}_{3}$, yielding a dose similar to the one given by Böttger et al. The reason for the absence of an IRI increase in the dogs could be either due to species differences or to the fact that other food constituents such as carbohydrate or protein are needed along with the $\mathrm{CaCO}_{3}$ to eause enhanced IRI release. The pancreatic and gut GLI and gastrin responses are now being investigated.

Acknowledgements. We wish to thank Dr. J. Schlichtkrull for eriticism and suggestions, Mr. A. Schaich Fries for performing the oral glucose loads in the rabbits, Mrs. M.P. Petersen for excellent technical assistance, and Mrs. Lene Drube for performing the polyacrylamide gel electrophoresis.

\section{References}

Böttger, I., Faloona, G.R., Unger, R.H.: The effect of calcium and other salts upon the release of glucagonlike immunoreactivity from the gut. J. clin. Invest. 51, $831-836$ (1972).

Chick, W.L., Like, A. A. : Effects of diet on pancreatic beta cell replication in mice with hereditary diabetes. Amer. J. Physiol. 221, 202-208 (1971).

Copinschi, G., Wegienka, Hane, S., Forsham, P.H. : Effect of arginine on serum levels of insulin and growth hormone in obese subjects. Metabolism 16, 485-491 (1967).

Fajans, S.S., Floyd, J.C., Knopf, R.F., Pek, S., Weissman, P., Conn, J.W.: Amino acids and insulin release in vivo. Israel J. med. Sci. 8, 233-243 (1972).

Floyd, J.C., Fajans, S.S., Conn, J.W., Knopf, R. F., Rull, J.: Stimulation of insulin secretion by amino acids. J. clin. Invest. 45, 1487-1502 (1966).

Floyd, J.C., Fajans, S. S., Conn, J.W., Knopf, R. F., Rull, J.: Insulin secretion in response to protein ingestion. J. clin. Invest. $45,1479-1486(1966)$.

Heding, L.G.: Determination of total serum insulin in insulin treated patients. Diabetologia $8,260-266$ (1972).

Heding, L.G., Rasmussen, S.M.: Determination of pancreatio and gut glucagon-like immunoreactivity (GLI) in nomal and diabetic subjects. Diabetologia 8, $408-$ $411(1972)$.

Knopf, R.F., Conn, J.W., Floyd, J.C., Fajans, S.S., Rull, J.A., Guntsche, E.M., Thiffault, C.A.: The normal endocrine response to ingestion of protein and infusions of amino acids. Sequential secretion of insulin and growth hormone. Transactions of the Association of American Physicians LXXIX, 312-321 (1966).

Malaisse, W.J., Brisson, G., Malaisse-Lagae, F.: The stimulus-secretion coupling of glucose-induced insulin release. J. Lab. clin. Med. 76, $895-902$ (1970). 
Malaisse, W.: Role of calcium in insulin secretion. Israel J. med. Sci. 8, 244-251 (1972).

Malaisse-Lagae, F., Malaisse, W.J.: Stimulus-secretion coupling of glucose-induced insulin release. III. Uptake of ${ }^{45}$ calcium by isolated islets of Langerhans. Endocrinology 88, 72-80 (1971)

Rabinowitz, D., Merimee, T.J., Maffezzoli, R., Burgess, J.A.: Patterns of hormonal release after glucose, protein, and glucose plus protein. Lancet 1966 II, 454-456.
Sukkar, M. Y., Hunter, W.M., Passmore, R.: Changes in plasma levels of insulin and growth hormone levels after a protein meal. Lancet 1967 II, 1020-1022.

Dr. L.G. Heding

Novo Research Institute

Novo Allé

DK-2880 Bagsværd

Denmark 